\title{
Don Quijote de la Mancha Reflexiones en torno a las relaciones cine-literatura
}

\author{
Don Quijote de la Mancha. \\ Reflections about the relationships between cinematography-literature
}

Felipe Ardila Rojas

Alfonso Cárdenas Páez*

Clásico no es un libro (...) que necesariamente posee tales o cuales méritos; es un libro que las generaciones del los hombres, urgidas por diversas razones, leen con previo fervor y con misteriosa lealtad. Jorge Luis Borges, Sobre los clásicos.

\section{Resumen}

Este artículo presenta un análisis de algunos aspectos de la relación cine-literatura, a partir del Don Quijote de La Mancha literario y de algunas versiones cinematográficas y televisivas realizadas en español y en inglés. Inicialmente se presentan problemas teóricos en torno a categorías que suelen serles afines: relato, autor, narración, historia, etc., para involucrar alternativamente fenómenos que, desde el punto de vista de los autores, generan ambigüedades textuales o múltiples interpretaciones en las versiones que se analizan. De este análisis comparativo que parte de los relatos en cuestión se llega finalmente a conclusiones de carácter estético e ideológico sobre los mismos.

\section{Palabras clave:}

Relato, diégesis, verosímil, discurso directo, discurso reportado, anacronía, plano, materias de la expresión, iconismo, analépsis, flashback, montaje.

\section{Abstract}

This article presents an analysis of some aspects of the relationship between cinematography and literature. Starting from the Don Quijote de La Mancha and taking into account some film and television versions developed in Spanish and English. At the beginning, a theoretical problem based on similar types for concepts categorization: author, narration, story, relat, among others will be analyzed. In addition, a connection is made with some authors' concepts in order to avoid textual ambiguity or multiple interpretations in the versions that are analyzed. Through a comparative analysis supported in these stories, it is possible to reach some aesthetic and ideological conclusions about them.

\section{Key words:}

Relate, diégesis, verosímil, direct speech, reported speech, anacronía, plan, matters of the expression, iconism, flashback, assembly.

Artículo recibido el 10 de marzo de 2008 y aprobado el 12 de mayo de 2008

* Felipe Ardila Rojas y Alfonso Cárdenas Páez, profesores de la Universidad Pedagógica Nacional. acardena@pedagogica.edu.co. 
En este espacio nos proponemos ordenar una serie de reflexiones en torno a las relaciones entre el cine y la literatura, que surgen a partir de Don Quijote de La Mancha, de Miguel de Cervantes Saavedra, y algunas de sus versiones cinematográficas o televisivas, entre ellas las de Orson Wells (1991 ¿?), Grigori Kozintzev (1957), Arthur Hiller (1972), Gutiérrez Aragón (1991, TV), Peter Yates (2000, TV) y Roberto Gavaldón (1973). Muchas más hay y aún de mucha importancia en términos cinematográficos: Méliès, Griffith, Lumet, Pabst, etc. La selección solo obedece a lo que se tuvo acceso.

Lo primero que habrá que aclarar aquí es que tenemos plena conciencia de encontrarnos ante dos tipos de relato, que implican, por esto mismo, lógicas narrativas distintas, aunque, por su puesto, encuentren aspectos en comunión.

\section{Los relatos}

"Soporte", "materia de la expresión"1, "sustancia de la expresión", "producto", “objeto real” etc., son algunos de los interpretantes del término "relato". Para ilustrarlo mejor, suelen señalarse ejemplos del tipo: "películas", "libros", “imágenes", “música”, "palabras". El relato de la obra de Cervantes está soportado únicamente por la palabra escrita. Aquellos que tengan ediciones con ilustraciones -son famosas y recurrentes las de Doré, las de Picasso y las de Dalí- sabrán que estas son posteriores a la primera y a la segunda partes de Don Quijote, y que sobre ellas nada entendió Cervantes². Claro, no olvidamos que en I, 9, cuando el narrador encuentra los cartapacios de Cide Hamete Benengeli, hace referencia a ilustraciones, entre ellas la de rocinante que citamos más abajo, pero que a nosotros no se nos muestran; de estas ilustraciones solo tenemos palabra escrita. Palabra escrita, pues, y en español de principios del

1 Esta es la expresión con la que más nos entendemos: “(...) est la nature matérielle (Physique, sensorielle) du signifiant, ou plus exactement du "issu" dans lequel sont découpés les signifiants (...) Ce tissu peut être phonique (=langage parlé), sonore, mais non phonique (=musique instrumentale), visuel et coloré (=peinture), visuel mais non coloré (=photographie en noir et blanc), il peut consister en mouvements du corps humain (=langages gestuels), etc. (Metz,1971: 157).

2 Cervantes, desde la definición de relato que adoptamos, vendría a ser "el relator"; el narrador es otro, anónimo en este caso.
$\mathrm{XVII}^{3}$. Estos apuntes dejan de ser triviales si tenemos en cuenta las investigaciones que corroboran los "cambios en la estructuración de la conciencia" (Ong, 1987) que provocó la escritura, en relación con la pura oralidad.

Ahora, si bien ha sido muy criticada la idea de "arbitrariedad" sea entre significante y significado o entre imagen acústica y concepto (Saussure) o entre representamen y fundamentum (Peirce) el rasgo se nos hace útil, en la medida en que nos guía hacia la ambigüedad del símbolo 4 . Esto es, en últimas, lo que provoca que cada lector concretice un Quijote, una diégesis ${ }^{5}$ del mismo, que, claro está, encuentra sus puntos de contacto con el imaginado o el ideado por otros, pero que, en fin, no va a ser nunca el mismo. Quien leyó el libro y posteriormente "asistió" a cualquiera de las versiones cinematográficas o televisivas -aun la de Gutiérrez Aragón- notará estas diferencias. Un simple ejemplo: frente a la palabra /caballo/ podemos hacernos una infinidad de imágenes. Aun si tratamos de determinar más el término, es probable que algún rasgo se nos escape: podemos leer sobre el caballo: “(...) y aunque tenía más cuartos que un real y más tachas que el caballo de Gonela, que tantum pellis et ossa fuit ${ }^{6}$ (...)" (I. 1) o "Estaba rocinante maravillosamente pintado, tan largo y tendido, tan atenuado y flaco, con tanto espinazo, tan hético confirmado, que mostraba bien al descubierto con cuánta advertencia y propiedad se le había puesto el nombre de Rocinante" (I. 9), podemos hacer énfasis en la flacura del rocín y aún así nos preguntaríamos sobre la gradación de los trazos: "qué tan flaco" o "qué tan alto". Problema, claro está, para quien hace el casting animaluno en

3 Sin olvidar que allí encontramos lengua arcaica para su tiempo, en la medida en que se parodian libros muy anteriores a El Quijote.

4 En términos de Peirce (La ciencia de la semiótica, p.e.), no de Saussure (Curso de lingüística generah), Peirce define el símbolo grosso modo como Saussure define el signo; por el contrario, el símbolo contiene para Saussure "un rudimento de vínculo natural" muy cercano a la noción de ícono en el primer autor.

5 "la diégèse nést donc pas l'histoire, mais l'univers où elle advient..." (Genette, 1983:13). No confundir con la diégesis que se opone a mimesis como formas discursivas, de origen platónico.

6 El pie de página de la edición de Planeta de Martín de Riquer, que seguiremos siempre aquí, dice sobre estas líneas: “Caballo de Pietro Gonella, famoso bufón (...), tan escuálido que 'todo era piel y huesos'", p. 37. 
esta película, quien además echará mano del "mundo de su vida", de lo que ese mundo le ha permitido "conocer" por "un caballo flaco". Por esto muchos lectores de Don Quijote encuentran en las versiones para cine y televisión caballos que bien poco ilustran las desventajas de rocinante (véase por ejemplo el robusto rocinante de Gutiérrez Aragón -para TVen la escena en que trata de seducir a las señoras "facas" (I. 15).

Este fenómeno se agudiza frente a aspectos en los que la palabra es pobre, como el color o el olor? Podemos ver una amplia gama de colores y distinguir una multiplicidad de olores que ninguna lengua está en capacidad de mencionar, a no ser a través de vagas analogías. En esta misma dirección, es propio del estilo cervantino no ser tan quisquilloso con esto de los trazos descriptivos. El color de rocinante no aparece por ninguna parte en Don Quijote literario, y es en este sentido muy semiótico que la mayoría de los rocines de las versiones sean blancos: Wells, Gutiérrez Aragón, Yates, Hiller y Kozintzev, versus el rocinante alazán que nos presenta Gavaldón.

Cualquiera de estas versiones de Don Quijote, sea la televisiva o la cinematográfica, está soportada en un relato cuyas "cinco materias de la expresión (...) tocan, como las diferentes partes de una orquesta, ora al unísono, ora en contrapunto..." (Jost y Gaudreault, 1995: 38). Esta constatación es la que ha llevado a muchos teóricos a desarrollar propuestas de análisis (véase Carmona, 1996, p.e.) que parecen sugerir la mayor complejidad de estos textos, frente a la de aquellos que solo se producen sobre la letra8. El caso es que desde tiempos lejanos son muchos los que han teorizado sobre la literatura y pocos y escasamente trabajados los que han teorizado sobre estos relatos de "mostración", para seguir el término de Gaudreault (1988). La escuela misma, solo hasta hace muy poco viene haciendo énfasis en este "de-

7 Esto nos da pie para recordar que todo ícono es también un signo y que como signo no es igual a la realidad. La noción de ícono, ya la antigua ya la de Peirce, ha sido hoy muy debatida y criticada. Véase, por ejemplo, Eco, Tratado de semiótica general. 3.5 Crítica del iconismo (1977).

8 Escribimos "letra" y no "escritura" por la ambivalencia que ha tomado esta última palabra en enunciados como "la escritura de imágenes" o “la escritura del cuerpo", etcétera. seo", que aun sigue siendo del arbitrio y posibilidades de los maestros. Estos estudios, generalmente, toman lugar en espacios académicos que le corresponden a la literatura, o en otros, ya de profesionalización en cine y televisión, hecho que señala una contradicción con lo que hoy es un motivo recurrente, llamar a esta época "la civilización de la imagen".

Claro, esta reticencia y atraso tal vez sean herencia de la dificultad que antes significaba enfrentar la película. El libro siempre ha estado en nuestras manos, podemos adelantar y retroceder las páginas, detenernos en un fragmento, dejarlo mientras preparamos el café, volver a donde habíamos quedado, etc. Parece elemental, pero con la película no siempre fue así, pues su espacio estuvo restringido a la sala de cine y a una proyección a la que no siempre o fácilmente se tenía acceso; hoy tenemos la película "en nuestras manos, podemos adelantarla y retrocederla, verla en cámara lenta, detenernos en un fragmento, dejarla mientras preparamos el café...

Sin entrar en polémicas sobre la mayor o menor dificultad en el análisis de uno u otro relato, lo que sí es evidente es que la pluralidad de estas materias de la expresión nos va a demandar conocimiento sobre cada una de las mismas, incluyendo la literaria, y capacidad para reconocer las virtudes o desventuras de la orquestación final, en la película terminada. Así pues, quien quiere ser "lector de segundo nivel" (Eco, 1979) de un texto cinematográfico, debe hacerse al discurso sobre la imagen en movimiento, sobre la fotografía, sobre la música, sobre la histriónica, sobre la misma literatura, sobre la historia misma de los productos fílmicos, etc., con el fin de acercarse un poco al ideal del lector modelo 9 , aquel capaz de cooperar en la actualización textual de la manera prevista por el autor, y de moverse interpretativamente, igual que él se ha movido generativamente. Tal vez, en esta línea, sean los premios que se dan en el cine los que corroboran esta sugerencia: la mejor película (la mejor orquestación, en últimas), el mejor actor (actriz), la mejor fotografía, la mejor banda sonora

9 Este concepto, aquí definido por Eco (1981: 77) se relaciona con el de lector implicado -y su paralelo, el autor implicado- de W. Booth y W. Iser, muy criticado por Gérard Genette (1983). 
(música, “ruidos", etc.), el mejor guión, etc., ejemplos que nos recuerdan, además, que sobre cada una de estas materias existe un discurso supremamente complejo en el sentido de "lo estético" o de lo que es arte y de lo que no lo es.

\section{El autor}

Esta breve reflexión nos introduce en el problema del autor.Sin desconocer la polémica sobre la autoría de la segunda parte de Don Quijote (la de 1614, no la primera de la primera parte de 1605.Y tampoco nos referimos a El Quijote de Avellaneda), es Miguel de Cervantes Saavedra el relator del Don Quijote literario. Para las versiones cinematográficas la autoría es cosa aun más compleja. Nosotros hemos sentido aquí ese problema, al escribir en los primeros párrafos el "de..." (Hiller, Yates, etc.), y hemos seguido esa tradición "falsa" pero "cómoda" de abrogar semejante título al director. Le hemos dado prioridad -rápida, ingenua- al director, por ser, las más de las veces, "el responsable último de la articulación del conjunto" (Carmona, 1996: 71), lo que no quiere decir que otras personas, encargadas de x materia de la expresión, no puedan imprimir mejor que este su sello artístico o sus ideas o percepciones sobre el mundo: el director de fotografía, el guionista literario, el productor o "la empresa" productora, el escenógrafo, quien dirige el montaje, etc., o que el relator sean todos (lo que se constituiría en un gran problema de "orden" para los eruditos del cine, los analistas, la escuela, etc., por supuesto).

En nuestros textos-objeto de interés, dos casos se hacen, en este sentido, más palpables que los demás: El Quijote dirigido por Gavaldón, en la coproducción México-España, resalta, ante todo y desde los paratextos ${ }^{10}$ que anteceden el inicio de la narración de la historia propiamente dicha, la presencia de Mario Moreno, "Cantinflas", como Sancho. En estos primeros créditos se lee: "Mario Moreno "Cantinflas" en Don Quijote Cabalga de Nuevo (...) con Fernán

10 La paratextualidad como una de las cinco formas de transtextualidad propuestas por Genette (1989) es la relación que mantiene el texto propiamente dicho con su entorno: título, subtítulo, intertítulos; prólogo, prefacio; notas al pie de página; ilustraciones, carátula, etcétera.
Fernández (...)", resaltando con el orden, el tamaño de la letra y la primera preposición la importancia mayor de este actor en el filml. Y es evidente que este Sancho sigue más fiel al imaginario de caracterización que nos han legado las películas de Cantinflas, incluyendo "Un Quijote sin mancha", que el mismo de Cervantes sobre la caracterización de Sancho. La impresión artística mayor es la de Mario Moreno y eso es lo que ha llevado a que en ciertas carátulas se diga "de Cantinflas", como autor de esta versión. Habrá, claro, quienes aleguen que no hay nada más parecido a Sancho que Cantinflas, y que a eso se debe la hipótesis. Nosotros consideramos que los discursos directos en gran cantidad de relato que se le dedican al personaje, la estructura total de esos registros, fenómenos paralingüísticos muy marcados del personaje, refranero al revés o en combinación, muletillas, etc., son indicios fuertes para sostenerla. Detengámonos un momento en la escena en la que defiende a Don Quijote frente al juez. Aquí una toma de primer plano nos muestra un escrito de Cervantes/personaje (aquí el escribano del juez) que dice: "en este loco hay un tipo para una novela" al lado de un dibujo que hace de don Quijote. El dibujo podría despejar la ambigüedad, si no fuera porque Sancho/ Cantinflas acaba de referirse a la bacía del barbero como si fuera el mismo yelmo de Mambrino, en el que ve oro, esmeraldas, rubíes, zafiros... A lo que el cura dice: "ve, señoría, cómo todo es locura", a lo que responde el juez/inquisidor: "Esa es la intención, hacerse el loco". Los planos han alternado entre Sancho, el cura, el inquisidor y Cervantes, más que sobre don Quijote, quien apenas se logra divisar en el fondo escenográfico, resaltando mejor la validez, por lo menos, de la doble lectura.

El segundo caso es el de la versión de Orson Wells: El Quijote de Orson Wells (1992). Sabemos que este fue un proyecto inacabado de Wells, cosa notable en el filme. Jess Franco (Jesús Franco Manera) dirige el montaje final y hace la posproducción, después de la muerte de Wells en 1985, con los materiales que encontró dispersos en manos de algunas personas en varias partes del mundo. Surge entonces la pregunta sobre el "verdadero" autor de esta película, cosa que se agudiza si tenemos en cuenta que el montaje es 
tal vez uno de los pasos más decisivos en la narrativa cinematográfica, tanto es así que en la mayor parte de las páginas de Internet que contienen la biografía de Jesús Franco, El Quijote de Orson Wells aparece como uno de sus filmes. Solo como guía utilizamos, pues, en este artículo los nombres de quien aparece como "director".

Podría sugerirse al respecto que estas ambigüedades autoriales hacen que las versiones se asemejen más a la literaria, en la medida en que Don Quijote plantea este tipo de problemática. Dos niveles distintos, sin embargo, habrá que tener en cuenta ante esta hipótesis: 1. Uno es el problema de "autor" a nivel de relato y sus materias de la expresión, es decir, de lo que hemos llamado el "relator", quien escribió Don Quijote (Cervantes biográfico, el hijo de Rodrigo de Cervantes y Leonor de Cortinas...) ${ }^{11}$; 2. Otro es el juego en la novela, con el término "autor", que provoca "el narrador", problema de la diégesis (este último, de "papel", ya parte de la ficción).

Sobre el segundo caso, que se deriva de fragmentos como: "Autores hay que dicen que la primera aventura que le avino (...)" (I. 2) o "(...) dijo que decía: Historia de don Quijote de la Mancha, escrita por Cide Hamete Benengeli, historiador arábigo (...) apárteme luego con el morisco (...) y rúguele me volviese aquellos cartapacios, todos los que trataban de don Quijote, en lengua castellana (...) le truje a mi casa, donde en poco más de mes y medio la tradujo toda, del mesmo modo que aquí se propone." (I. 9), Martín de Riquer señala que Cervantes trata con ellos de parodiar "un aspecto del estilo de los libros de caballería, en los que es muy frecuente que los autores finjan que los traducen de otra lengua (...)" y posteriormente nos da ejemplos de ello ${ }^{12}$. En este caso, Riquer parece tener muy claro la diferencia Cervantes/Narrador (N.N.). Antes ha dicho que: "Cervantes ha fingido ser una especie de erudito que recopilaba datos de otros autores (...) Cervantes se nos introduce él mismo en las páginas

\footnotetext{
11 Adelantemos con la cita de Balzac: “( ...) muchas personas hacen aun hoy el ridículo al otorgar al escritor sentimientos que él atribuye a sus personajes; y si emplea el yo, casi todos están tentados a confundirlo con el narrador". Prefacio a El lirio en el valle.

12 Pie de página al cáp. 9 del tomo I.
}

de la novela apesadumbrado por no saber más de don Quijote (...)". Aquí tenemos la impresión de que don Martín de Riquer confunde las dos instancias mencionadas en el párrafo anterior. Que esta confusión se presente a nivel de los paratextos: los prólogos, las dedicatorias, vaya y venga, pues la relación de comunicación que se establece es otra, el pacto de lectura ${ }^{13}$ es otro. Cuando se inicia la narración de la historia propiamente dicha: "En un lugar de la Mancha de cuyo nombre..." cambia este pacto, so pena de vernos obligados a considerar -por error- que Cervantes no es el autor de Don Quijote, sino apenas una especie de acotador a la traducción del autor Cide Hamete, hecha ya en su casa por el morisco -véanse citas más arriba- o alguien que tuvo la suerte de hallar los manuscritos; el nombre de Cervantes solo aparece en el famoso episodio del escrutinio, como el autor de La Galatea (I. 6), y ni siquiera este apellido "declarado" dentro de la ficción literaria podría establecer la identidad Cervantes real/Narrador ficcional ${ }^{14}$, so pena de caer en la misma locura de don Quijote.

En la versión cinematográfica de Gavaldón, "Cervantes" aparece como personaje de la historia -un escribano del juez-; en la versión de Gutiérrez Aragón, "Cervantes" aparece "leyendo" los manuscritos en un raccord a un plano medio muy breve durante la escena del famoso escrutinio, y en el momento en que encuentra los manuscritos que dan cuenta de la continuidad de la historia del gallardo vizcaíno, en una escena con mayor tiempo de relato. Aquí no se dice "este es Cervantes". Lo suponemos, porque en el momento en que el cura habla de Cervantes y $L a$ Galatea, aparece el plano intercalado del personaje

13 Ph. Lejeune, Le pacte autobiographique, Paris, Seuil, 1975, pp. 19-35. El autor de novelas pide implícitamente a su lector que "imagine" como verdadero o posible lo que le va a contar, aunque esta pretensión casi nunca esté formulada directamente.

14 Sobre este proceso de comunicación-al que llaman comunicación "narrativa" -han hablado muchos teóricos, entre ellos W. Booth, Chatman, Mieke Bal, Bronzwaer y G. Genette. Aquí vamos a reducir el cuadro de las figuras diferenciadas, teniendo en cuenta, precisamente, las discusiones que estos autores proponen frente a las mismas (salen, pues, las figuras "implicadas" y dejo también las laterales, por lo que se leerá después) y agregando la instancia a la que "pertenecen": Autor real (relato)-Narrador- (Narración)Narratario-Lector real (relato). 
"Cervantes" leyendo los manuscritos, personaje que encadenamos luego con la otra escena mencionada; en la versión de Hiller, más compleja en este sentido, "Cervantes" es un teatrero y escritor, que representa aquí como actor, a don Quijote; la versión de Wells (¿?), como la anterior, también es más compleja. Al inicio del relato aparece una voz en over ${ }^{15}$, la de Wells, quien pareciera seguir, en versión entrecortada, la lectura del Don Quijote, que acompaña y se intercala con las imágenes de los personajes don Quijote y Sancho, entre otros, y sus diálogos. Posteriormente nos aseguramos de que la historia transcurre en la España contemporánea a Wells y que este aparece como personaje, lo que convierte la voz en off y en in -esto, aun reconociendo la variedad de voces que acompañan a cada personaje en esta película-. Todo este juego nos propone la transposición Wells/ Cervantes, lo que nos lleva a interpretar la película en otros términos. Posteriormente oiremos a Wells haciendo una reflexión sobre don Quijote, a quien halaga como "el verdadero caballero", lo que no deja inválida la transposición sugerida.

Los datos del párrafo anterior sirven para señalar el hecho de que esta confusión: Cervantes/narrador o autor real/narrador se presentan también en algunas versiones cinematográficas, a excepción de las dos últimas mencionadas, que parecen presentarnos un tratamiento más profundo y problemático, que dejamos, por ahora, inconcluso.

Una última acotación sobre el autor en el cine o en la televisión. Existe la expresión recurrente entre los cinéfilos que es la de "cine de autor". Expresión demasiado ambigua que parece señalar varias concepciones: 1 . El director que en varias de sus películas ha logrado imprimir cierta cualidad, cierto estilo que los cinéfilos reconocen, y que puede darse o bien a nivel de cualquiera de las materias de la expresión, o bien a nivel de cierta ideología implícita; 2. A quienes se les atribuye un tipo de cine, con características difusas, pero que, digamos, no sigue

15 “(..) voz in (...) la voz que parece salir de la boca de un personaje presente en el encuadre (...) la voz off (...) la voz del monólogo interior o del personaje narrador (...) no presente en el encuadre (...) la voz over (...) se instala en paralelo a las imágenes (...) emergiendo de una fuente exterior a los elementos que intervienen dietéticamente en el film" (Carmona, 1996: 108). al pie los cánones del llamado -y también ambiguo"cine comercial"16: sistemáticos motivos recurrentes, mucha acción, analogías musicales explícitas, happy ends que conceden con los sufrimientos y deseos del espectador, repetición de imaginarios populares, etc.; 3. Una sola persona que es, a su vez, el encargado de varias materias de la expresión: hace la fotografía, escribe el guión, actúa, dirige, produce. Generalmente se debe a falta de recursos, etc. Tal vez la figura, en este caso, que mejor logra "cuadrar" en medio de estas ambigüedades es, sin duda, Orson Wells.

\section{Mitos}

Ahora bien, cabe aquí detenernos un momento en "la fama" o en el mito que suele hablar17 a personajes como Mario Moreno, "Cantinflas", o Wells. Sabemos que la presencia de estos ya como actores ya como directores, etc., en las versiones del Quijote, afectan la recepción del texto. Son, en últimas, "clásicos", hitos cinematográficos, como lo son también Peter O'Tool y Sophia Loren, Nicolai Tcherkassov, Fernando Rey, etc. Su presencia afecta la recepción, en el sentido en que, ante tanto mito, nos vemos, primero, obligados a callar frente a sus actuaciones $y$, segundo, a sumar el mito acumulado a lo que ahora presenciamos. Si se nos aviene la crítica, esta se hará en voz baja las más de las veces, sobre todo ante los "conocedores de la materia" y, peor, ante quien "responde al mecanismo constitutivo del mito, a su dinámica propia"18. Don Quijote literario es, por supuesto, un clásico de la literatura universal, un intocable. Recorremos sus páginas como si en ellas "todo fuera deliberado, fatal, profundo como el cosmos y capaz de interpretaciones sin término (...) con previo fervor y con misteriosa lealtad" (Borges,

16 Películas que "estimulan las sensibilidades (...) que están relacionadas con valores tradicionales (...) indiscutidos y que repiten hasta la saciedad lo que todos admiten sin resistencia alguna (...) legibilidad máxima: claridad y simplicidad, nada de imprevistos, linealidad sin tropiezos, convencionalidades, clichés...", la forma espuria de la cultura de masas -decía Roland Barthes-, es la repetición vergonzosa: repite los contenidos, los esquemas ideológicos, la difuminación de contradicciones, pero varía las formas superficiales" (...)" para seguir a Ignacio Ramonet en Propagandas silenciosas. Edi. Valquiria. Venezuela (sin año de publicación).

17 Siguiendo, en fin, la problemática del mito a la manera de Roland Barthes en Mitologías (1957).

18 Ibíd, p. 221. 
1980). Un ejemplo de este lector lo muestran las no pocas líneas en que Martín de Riquer regaña a quien se atreve a postular errores en Don Quijote: “(...) peca precisamente por su neoclásica manía de señalar errores gramaticales a Cervantes y de enmendarle la plana. Muchas veces Clemencín no tiene razón, ya porque no ha entendido el texto, ya porque no se ha dado cuenta de que el problema es distinto"19, así se trate del mismo Diego Clemencín quien es para muchos el primero y más grande comentarista de Don Quijote.

Los profesores - de bachillerato, universitarios, sobre todo- tendemos a "enseñar" toda la mitología literaria, a seguir reproduciendo el habla sobre los clásicos, más que porque en ellos encontremos la "verdad" literaria o la "verdad" cinematográfica, porque ellos nos permiten el orden en el mundo caótico y cuasi infinito de las producciones, nos proponen un límite. Las teorías de la recepción, sin embargo, nos formulan en este sentido, el caos, el mundo heteróclito de los lectores o de los espectadores. Encontramos hoy, lo más común, estudiantes que "aborrecen" sin empacho a Don Quijote, solo de verlo -el síndrome del mamotreto (que nos alerta, además, como un contrasentido, sobre Harry Potter, también mamotreto, de J.K. Rowling) -, que no le encuentran la gracia o les parece ingenuo, que no encuentran en él nada "para sus vidas"; estudiantes que solo al notar el blanco y negro y los problemas de grabación de El Quijote de Orson Well se duermen o se retiran de la sala; estudiantes cuya cultura letrada es mínima y cuya cultura cinematográfica solo asume los textos que los cinéfilos llaman "comerciales", etc. En fin, el maestro se esfuerza -a menudo a la fuerza- por obligar el gusto, cosa que, en ocasiones pocas, rinde sus resultados. Claro, las más de las veces, cuando ese profesor asume el mito (pie de pág. 14) no suele presentar discursos muy lógicos o fuertemente argumentados, sino, más bien, sensibles, lo que cualquiera tiene sobre los gustos de su propia "enciclopedia".

Este discurso mítico puede dar lugar, además, a la hipótesis radical de "el purista" que niega la posibilidad de la "traslación" al cine o a otro medio

19 Introducción a la edición de Planeta, p. LXVI. o la "traducción" de Don Quijote a otros idiomas. Sobre este aspecto se encuentran sí muy buenos y fuertes argumentos, que nos llevan, sin embargo, a la indeseada, imposible y poco funcional conclusión de aprender -en igualdad a la lengua maternatodas las otras lenguas en las que deseemos leer $\mathrm{X}$ textos literarios "clásicos", a empaparnos -también como en la lengua materna- de todos los dialectos de esa misma lengua que puedan estar presentes en los textos literarios, a sumergirnos en la época -el Quijote lo demandaría- para reconocer los valores "en el tiempo" de palabras y expresiones, etc., etc. La expresión de estos apuntes llanos pueden leerse en muchos de los textos que componen la ya desmesurada exégesis del Quijote. La crítica que hace José Nieto a la versión de Kozintzev, si bien trata de la banda musical, lo mismo nos ilustra al respecto: "Sin embargo, en un par de secuencias, los campesinos manchegos cantan y bailan al son de guitarras y castañuelas una extraña mezcla de tanguillo y sevillanas que, naturalmente, nada tiene que ver con la época ni el lugar en el que transcurre la acción". O a la de Hiller: "Con un planteamiento musical y dramático de los personajes en el que se mezcla lo directo con lo banal y se confunde la emoción con la cursilería, fórmula frecuente en el género, El hombre de La Mancha constituye uno de los mejores ejemplos sobre la frivolidad con que, a veces, ha sido tratada la obra cumbre de Cervantes en su traslación a otros medios" 20 .

El orden es, siguiendo esta línea, fundamental en la recepción de los textos. Leer primero Don Quijote y luego ser el espectador en una sala de cine o frente al televisor, no suele ser lo mismo que el proceso inverso. Aquí el orden de los factores si altera el resultado. Para uno de esos estudiantes que nunca ha sabido nada del Don Quijote -los hay, y a nivel universitario-, una versión cinematográfica $\mathrm{X}$ que en poco siga la literaria, puede parecerle "buena" $\mathrm{y}$ hasta llevarlo al engaño de creer que ahora ya "conoce" el Don Quijote literario. En este sentido, no conocer el libro suele ser ganancia para la película y

20 Nieto, José. Don Quijote de la Mancha. Música y cine. En http:// cvc. Cervantes.es/actcult/quijote_musica/Nieto/htm. 
para la "buena" sensibilidad del estudiante frente a la misma: digamos que los procesos de identificación ${ }^{21}$ con el universo diegético serán más fáciles. Además, conocerlo, y por asiduo lector, suele llevar a que se le pida al texto cinematográfico más de lo que puede dar en términos de los mecanismos de expresión de la literatura. Este espectador estará más del lado del distanciamiento, del control del relato, que del de la inmersión en la diégesis.

Hemos visto cómo el cine norteamericano ha sabido inundar con su producción la mayor parte de los países, imponiéndose desde hace ya varias décadas en el consumo frente a las producciones locales. El triunfo (en este sentido) del cine norteamericano se debe, entre otras cosas, a una eficiente y sistemática publicidad que gira en torno a la popularidad (digamos a la construcción del mito) de sus actores. Actores como "Humprey Bogard o Marilyn Monroe han perpetuado su efigie mucho después de la muerte. El público llega a identificarse con la ficción hasta el punto de imitar a sus ídolos" (Porter y González, 1988: 70). Este tipo de publicidad, muy eficiente en términos del consumo, llena, sin embargo, de vacío el discurso de los espectadores en torno a la histriónica y sus problemas estéticos; por el contrario, el cine de los países de Europa basó su publicidad -en últimas también una construcción de mito- en los directores y productores cinematográficos, a partir de un habla diferente, tal vez más afín al cine y a sus problemas estéticos, más intelectualizada y más compleja, que "perdió" ante el embate de un discurso trivial, cercano a "otras cosas de la vida personal de los actores", de mucho más fácil consumo. Estas diferencias conducirán, lo creemos aquí, a una mirada y tratamiento diferentes cuando de enfrentar la transposición de esos grandes "clásicos de la literatura universal" se trata.

21 Metz (1979) parte de dos tipos de identificación cinematográfica: una primaria, en la que el espectador se identifica con la cámara, como mirada; y otra secundaria, en la que se identifica afectivamente con tal o cual personaje de la ficción cinematográfica. Debimos puntualizar arriba "con un personaje de la diégesis". Nótese la relación a la catarsis aristotélica. Este término nos remite al otro, el de distanciamiento, más pensando en Bertold Brecht, como el concepto contrario, del espectador que tiene conciencia del relato, que lo percibe sin identificarse de ninguna manera con nada del universo diegético.
Una última apreciación teórica, antes de iniciar un recorrido breve -el espacio así lo implica- por las películas propuestas. Utilizaremos el término comprender la información textual en el sentido de no aberrar (Eco, 1977) la información que este nos presenta. Esta noción suele ser abarcada por ciertas acepciones del término interpretar que dejamos para "lecturas" que involucran toda la enciclopedia del lector, que este relaciona con lo que está leyendo o percibiendo. Todos podemos, luego de la lectura del Don Quijote, estar de acuerdo en que don Quijote se convierte en caballero solo porque está loco: “(...) se enfrascó tanto en su letura, que se la pasaba las noches leyendo de claro en claro, y los días de turbio en turbio; y así, del poco dormir y del mucho leer se le secó el celebro, de manera que vino a perder el juicio..." (I. 1); pero ante la afirmación "don Quijote se convierte en caballero debido a la lascivia reprimida que siente por su sobrina" -y el ejemplo no es nuestro-, muchos verán una ilustración de interpretación extrema.

\section{Transposición, omisión, re-creación (las versiones "libres")}

\section{Los eventos}

La historia total del Don Quijote contiene una gran cantidad de eventos, con su debida cronología, que difícilmente una transposición cinematográfica "pretendida fiel" al libro podría abarcar, a no ser que se pensara en una secuencia al estilo de El padrino, basada en la novela de Mario Puzzo, y más extensa, o en los formatos hoy sistémicos de los Rocky, de Silvester Stallone, por ejemplo. Esta selección de los eventos a presentar o a omitir o a fundir tiene ya sus significaciones, aunque estas, claro está, estén para nosotros en los estadios de la interpretación. Tomemos, para iniciar e ilustrar este apartado, la primera salida de don Quijote: 1 . Sale de su casa (sin Sancho); 2. Llega a la venta; 3. Encuentro con las mozas; 4. Encuentro con el ventero; 5 . Las mozas tratan de desarmar a don Quijote, sin poder desatarle la celada; 6. Tratan de alimentar a don Quijote, con la celada puesta; 7. Don Quijote hace la vela de las armas; 8. Enfrentamiento con el primer arriero, a 
quien golpea en la cabeza; 9. Enfrentamiento con el segundo arriero, a quien le rompe la cabeza; 10. Lo apedrean; 11 . El ventero calma los ánimos e inicia el nombramiento; 12 . Se despide don Quijote y sale de la venta; 13. Encuentro con el labriego que azota al muchacho Andrés; 14. Don Quijote “negocia” con el labriego la deuda de Andrés; 15. Don Quijote se aleja; 16. El labriego vuelve a golpear a Andrés y luego lo suelta; 17. Encuentro con los mercaderes toledanos; 18. Don Quijote ataca a uno de los mercaderes; 19. Rocinante tropieza y caen los dos al piso; 20. El mozo de mulas golpea hasta el cansancio a don Quijote, que yace en el piso; 21. Lo encuentra un labrador vecino, Pedro Alonso, lo monta en su borrico y lo lleva a su casa, donde lo esperan el barbero, el cura, la sobrina y el ama...

La única de las versiones mencionadas aquí que sigue "fiel" -hasta donde es posible el término y sin referirnos a los diálogos- esta secuencia de acciones es la de Gutiérrez Aragón para TV (Fernando Rey -Don Quijote- y, Alfredo Landa -Sancho-). Las otras incluyen a Sancho desde el inicio y en esta salida y, por tanto, se ven obligadas a trasladar diálogos o a proponerlos y a re-crear las escenas. Esto muestra sin dudas la importancia que los lectores dan a este personaje y muestran ya la necesidad de comprimir eventos para las versiones cinematográficas o para las televisivas hechas como largometrajes (Yates). Estas otras versiones omiten también los eventos relacionados con el encuentro de don Quijote y el joven Andrés -excepción de la de Kozintzev también, pero con Sancho-, cuya importancia es sustancial en Don Quijote, pues marca desde el inicio el carácter irónico y trágico a que suelen conllevar las acciones de don Quijote, en el sentido en que hacen más mal que bien (en el mundo de la cordura, muy diferenciado en la novela). Las interpretaciones que de aquí pueden surgir están ligadas a ese sentido de justicia del que el Don Quijote es un símbolo recurrente, cuya construcción dejamos a los lectores. En Yates y en Gavaldón en este primer espacio de la venta en que don Quijote se arma caballero -ventas hay más de una- se introduce el famoso "manteamiento de Sancho" que se da en I. 17, cosa que no nos parece tan desacertada.
Uno de los eventos sine qua non de las versiones y, en últimas, del imaginario general sobre Don Quijote, es el de los molinos de viento (I. 8). Este hecho, el que por antonomasia los molinos sean la representación de Don Quijote, es ya lugar obligado de interpretaciones. Podríamos considerar por ahora que lo importante de este, fuera de encontrarse en los primeros capítulos (sentido en el orden) es que, olvidando los daños materiales, es don Quijote el único lastimado; no hay, pues, repercusiones en terceros, como en la mayor parte de los otros eventos: el mozo Andrés azotado (I. 4), los galeotes liberados y los guardias malheridos (I. 22), los arrieros golpeados (I. 3), el vizcaíno aporreado (I. 9), la mortandad de carneros y ovejas (I. 18)22, etc., y en cambio sí señala la magnitud simbólica de las hazañas e hiperboliza su sentido de la justicia, que va muy bien con el mito más recurrente-claro, es interpretación nuestra-, de Don Quijote. En todas aparece, aunque en Gavaldón es parte del sumario que se nos muestra, sin voces in, en medio de los créditos iniciales. En Kozintzev este episodio aparece después de la salida del castillo de los duques, relatado en la segunda parte, ejemplo del desbarajuste que crea este director $-\dot{\imath}$ o el guionista? - entre el tiempo del relato y el tiempo de la historia ${ }^{23}$, así como con el manejo de los espacios diegéticos. Pero lo que más resalta en el tratamiento de este evento es que la acción se muestra más espectacular de lo que en el texto literario se dice: 1. Se encuentran con treinta o cuarenta molinos de viento; 2. Una ráfaga de viento comienza a mover las aspas; 3. Don Quijote se va lanza en ristre contra los molinos; 4. Las aspas se llevan "tras sí al caballo $\mathrm{y}$ al caballero, que fue rodando muy maltrecho por el campo"... En Yates y en Hiller don Quijote queda atrapado por el asta y da vueltas con ella, para luego caer desde arriba -en la segunda no tanto- y salir vivo de semejante golpe -como en las tiras cómicas-

22 Notemos que la segunda parte de Don Quijote adolece de este tipo de estructura, frente a lo que ha sido la primera.

23 En Genette (1983), el tiempo del relato es el tiempo de lectura, que obedece además a fenómenos espaciales, como cantidad de fragmento escritural dedicado a tal evento, descripción, etc; el tiempo de la historia solo puede ser cronológico, pues sigue el orden lógico de los eventos, de las acciones de los personajes. El relato, por supuesto, trastoca siempre esta cronología de la historia. 
lo que sin duda afecta el trabajo de verosimilitud ${ }^{24}$ $\tan$ bien desarrollado en el texto literario, y que nos arrastra a los juegos bien definidos de cordura/ locura establecidos por la narración y el foco de los personajes; en el sumario de Gavaldón, en el que también se alude al enfrentamiento con los cueros de vino, al enfrentamiento con las ovejas y al yelmo de Mambrino, la cosa se pone peor, pues en este girar de las aspas también va Sancho encaramado, lo que da pie a la aparición del Cantinflas que el actor lleva dentro, y nos avisa, de entrada, el importante rol del Sancho de este relato. No dejan por esto de ser atractivas las imágenes de este episodio, muy bien logradas, sobre todo en Hiller, y su sentido del vértigo. Por el contrario, Gutiérrez Aragón y Wells se ciñen más al texto, no solo en este sentido, sino, además, en la "mostración" del foco de don Quijote, que está más recargado en lo literario que en lo visual (lo que en el cine suele ser más "una falla"). Yates, en particular, hace gala de los efectos especiales, mostrando el foco de don Quijote, con gigantes que surgen de las figuras de los molinos: muy al estilo americano, dirán los unos, muy cinematográfico, dirán los otros.

Resaltamos aquí, además, dentro del "desorden", en relación con el relato literario, propuesto por kozintzev, el episodio del manteamiento de Sancho. Este se nos muestra a la salida del castillo de los condes, llevado a cabo por personajes propios a este cronotopo ${ }^{25}$. Ahora Sancho no es manteado por gente de su misma condición, no es, digamos, burlado

24 Tomas Albaladejo (1992), a partir de tres tipos de modelo de mundo posibles en la novela, nos define el término verosimilitud. El modelo que llama de tipo II es, creemos, el que se acerca más a nuestro imaginario sobre Don Quijote: "un modelo de tipo II lo que hace es construir una serie de instrucciones que no son propias de la realidad efectiva, con la que, sin embargo, mantiene una relación de semejanza. De estas instrucciones dependen seres, estados, procesos, acciones e ideas (...) la estructura (...) que el productor constituye de acuerdo con este modelo de mundo está provista de verosimilitud (...) en la medida en que el modelo de mundo está formado por reglas equivalentes a las de dicha realidad". Podemos añadir, además, y a partir de lo anterior, la contundente frase de Aumont, J. y otros (1985: 142): “Se estima verosímil lo que es previsible".

25 El cronotopo es “la conexión esencial de relaciones temporales y espaciales asimiladas artísticamente en la literatura (...) los elementos del tiempo se revelan en el espacio, y el espacio es entendido y medido a través del tiempo (Bajtín, 1989: 237). por ellos, sino por "la nobleza", que se pinta tal vez más despiadada que en el libro mismo: muy al estilo de "la antigua Unión Soviética", dirán los unos; tal vez la versión mejor lograda, dirán los otros.

Otras de las omisiones importantes de este último director que llevan a interpretaciones o búsqueda de "sentido" y que aquí solo señalamos, son las relacionadas con el donoso y grande escrutinio en la biblioteca de don Quijote (I.5), el nombramiento en la venta (I.3) y la desaparición de Ginés de Pasamonte -aunque aparecen los galeotes- en todo el relato, con los eventos posteriores en que este se implica. Por su parte, Wells, más que transponer, omite, y más que seguir evento tras evento la historia, transforma y propone. Al inicio vemos a un Wells (actor/ director dentro del filme) entrando a la ciudad en el Mercedes "oscuro" (la película es en blanco y negro, lo que, sin duda, aporta "sentido", luego un plano/ secuencia breve sobre él en el que toma la cámara y enfoca... a la cámara, se intercalan imágenes de edificios, aspas de molinos en movimiento, calles, panorámicas, estatuas de don Quijote y Sancho, de Cervantes. Escuchamos la voz que viene siguiendo la lectura sintética y sobresaltada de Don Quijote y que se intercala a su vez con diálogos entre los dos personajes, lo que pareciera presagiar un recorrido análogo -esto, además, indicado por una caracterización "fiel" de los dos personajes centrales- pero no tarda el texto en deslumbrarnos: una furibunda labradora en una "máquina infernal", con la que casi lo atropella, una motoneta, enfrenta a don Quijote; de aquí en adelante no es raro ver antenas de TV, a Sancho y a don Quijote en una chatarrería de carros y aviones, etc. Entonces entendemos que su pretensión no era la misma de Gutiérrez Aragón o la de Yates, sino la creación de toda otra cosa, un Don Quijote anacrónico, un Don Quijote en o de la mitad del siglo XX. Esta "actualización" del Don Quijote y, al mismo tiempo, esta anacronía del personaje hacen, desde otro punto de vista, fiel este Don Quijote al literario, en la medida en que el personaje del literario es también anacrónico para su época. Recurso inteligente, hacer sentir al espectador la misma sensación que los lectores antiguos sentían con su Quijote, al reconocer su desfase temporal. 
Vemos, pues, un don Quijote y un Sancho muy cercanos a la caracterización del libro, una buena porción de discursos directos, de diálogo entre estos dos personajes, muy cercanos al texto -como los eventos, extraídos de aquí y allá, sin seguir el momento preciso en que aparecen en el libro-, y unas pocas acciones que conocemos: grosso modo la penitencia en Sierra Morena, el enfrentamiento con el rebaño de ovejas y la consecuente apedreada, la aventura con los molinos de viento (nótese ya el des-orden entre las dos anteriores) y el engaño de Sancho a don Quijote con la labradora/Dulcinea. Entre estos eventos vemos a un Sancho buscando a través de un telescopio a su señor en la luna -muy poética, densa, la figura-, a Sancho entre los toros de San Fermín, planos de Wells y su voz (i? Aquí hay un juego con la voz y sus sistemáticos cambios, bien difícil de discernir) hablando de España y de don Quijote, a Sancho trabajando para una película de Wells, a don Quijote hablando en contra de las cámaras de cine, los personajes escuchan la radio, se habla de cohetes, misiles, Guerra Fría... Todo esto "declara" la propuesta diferente que no pretende ejercer el trabajo del traductor o del "trasladador" que vemos en Gutiérrez Aragón o en Yates -claro, con un poco de ingenuidad-, y que exige, por tanto, la lectura diferente.

En este sentido, es también interesante la versión de Hiller (1972), quien sigue la obra para Brodway de Dale Wasserman (1966). La película/musical ( $i$ ? el texto de Wasserman) presenta dos universos diegéticos separados. Por una parte, el de Cervantes/ personaje, teatrero que monta en la cárcel un Don Quijote, con su ayudante, él mismo y los presos como actores; por otra, el de don Quijote en un cronotopo distinto. Debe suponerse, claro está, que los personajes de la segunda diégesis están siendo actuados adentro del cronotopo primero; que la expresión que nos muestra la segunda diégesis es "cosa del cine". A este reconocimiento de anclajes y desanclajes nos llevan los planos que alternan entre uno y otro escenario, entre el dentro y el afuera de la cárcel, entre la representación englobante y la englobada, entre la realidad -dentro de la ficción-y la ficción -dentro de la realidad-; la ficción dentro de la ficción, lo que es común en el Don Quijote literario, juego que nos genera con mayor fuerza la ilusión de realidad. Conjuga entonces esta versión biografía cervantina, por un lado, y una propuesta de Don Quijote, por otro.

Claro, la propuesta estructural de estas dos interesantes versiones, la de Hiller y la de Wells, pudo partir del error de lectura que mencionábamos más arriba, el de confundir al narrador con Cervantes. De ahí la presencia de Wells en el filme; de ahí la presencia de "Cervantes" como teatrero dentro del filme de Hiller.

\section{Actores}

\section{Maritornes/Dulcinea/Aldonza (un ejemplo)}

Maritornes es, sin duda, uno de los personajes femeninos más importantes de Don Quijote. Ella es "ancha de cara, llana de cogote, de nariz roma, de un ojo tuerta y del otro no muy sana (...) y las espaldas, que algún tanto le cargaban, la hacían mirar al suelo más de lo que ella quisiera (...) el aliento pudiera hacer vomitar a otro que no fuera arriero (...)" (I. 16). $Y$ suele en el cine transformarse en otra cosa. En Hiller, por ejemplo, se le encarga el rol a la actriz Sophia Loren, que por más despelucada y sucia no logra, sin embargo, seguir ni de cerca la caracterización propuesta. Claro, ella aparece como una fusión de Aldonza Lorenzo, "moza de muy buen parecer", fusión que parece motivada por los imaginarios de la industria cinematográfica, y que por supuesto intentan limpiar al Don Quijote (de Cervantes) del discurso escatológico que, muy a menudo, en él se presenta. Esta misma transposición se da también en Gavaldón, en la que Aldonza (nombre)/Maritornes (ciertos rasgos) está a cargo de María Fernanda d'Ocon. En las dos versiones mencionadas esta fusión ocurre en la primera venta, que puede determinarse porque es allí donde don Quijote se arma caballero. Ya sea Aldonza ya Maritornes, en las películas este personaje toma mucho más relato del que en el Don Quijote literario tiene, lo que nos guía por el lado de "las versiones libres", acotación que todos los críticos, directores y productores se ven obligados a reseñar. Tanto en Hiller como en Gavaldón estas 
Aldonzas/Maritornes se pasean por la mayor parte de los espacios de la historia, hasta aparecer en el lecho final de muerte. Es como si el imaginario de los relatos cinematográficos obligara a volver carne lo que en El Quijote es idea: Dulcinea. Convencido por esta Aldonza/Maritornes/Dulcinea don Quijote vuelve a cabalgar con Sancho, en Gavaldón; entre los brazos de Aldonza/Maritornes/Dulcinea y en medio del canto muere don Quijote en su locura en Hiller; y aunque con un tratamiento diferente, la Aldonza/ Dulcinea (Vanesa Williams) de Yates aparece en el lecho de muerte, lo besa en la frente para que don Quijote muera, después del "thank you, my lady Dulcinea", con una última imagen en su cabeza: los dos cabalgando en rocinante hacia las estrellas $-{ }^{\circ} \mathrm{O}$ hacia el cielo? -. Estas tres películas se resisten a la muerte de don Quijote en la cordura, "cordura cristiana”, como lo señalaría Harold Bloom (1997): en esto no hay dudas, don Quijote literario muere y muere cuerdo, como Alonso Quijano, el Bueno, pidiendo "déjense burlas aparte" (II. 74)26. Esa expresión de resistencia de estas versiones cinematográficas no parece otra cosa que la analogía de la permanencia en Occidente de todo el ideal -limpio ya de las ambigüedades del texto, tal vez más posicionado en una actitud escéptica- mítico que se ha construido sobre don Quijote -otra vez, interpretación nuestra.

\section{Otros sobresaltos}

Ya lo mencionamos, la versión de Wells nos muestra una "actualización” de Don Quijote, que declara abiertamente con la contundencia de las imágenes y los contenidos literarios. Las de Gutiérrez Aragón, Kozintzev, Hiller y Gavaldón siguen hasta donde la fidelidad es posible, el imaginario cronotópico que propone el Don Quijote literario, con todo lo demás

26 Es posible sostener que este escepticismo, que se niega sistemáticamente, pero que textualmente es explícito, es lo que convierte a Don Quijote en una verdadera novela, en el mayor hipotexto de todas las posteriores, y no en un novelón más parecido a las telenovelas actuales, el de la concesión con el lector y el happy end. El Quijote es pues "la melancolía profunda del curso mismo de la historia" (Lukács, 1975). La otra cosa sucede, más bien, con las novelas ejemplares, aun las incluidas en Don Quijote; claro, para tornarnos más polémicos, también es posible alegar que Don Quijote concede, al final, con el ideal de la cristiandad, lo que no es menos fuerte. que esto implica: vestuario, arquitectura, ciertos objetos, etc. Y se esfuerzan en ello. La de Yates, en ciertas ocasiones, parece toda otra cosa: el cronotopo y su mundo diegético se nos vuelve ambiguo ${ }^{27}$. El vestuario, la arquitectura, la biblioteca, la limpieza... Indicios nos van conduciendo a la hipótesis, que luego se nos presenta contundente: Sancho le pregunta a don Quijote "cuánto paga el honor por hora", su casa -la de Sancho- no delata las grandes diferencias sociales, que sí vemos, por ejemplo, en Gutiérrez Aragón, ni el juego de los condes aparece tan dramático como en el Don Quijote literario o como en la versión de Kozintzev. La vestimenta, en particular, de los condes y sus sirvientes: mucamos en corbatín, se nos hacen más de principios del XIX que de siglos anteriores, etc...

El tratamiento del personaje de Sancho no presenta graves complicaciones en la mayor parte de las versiones, salvo algunos trazos de caracterización que llaman la atención: el Sancho sin barba, por ejemplo, de la que mención se hace en no pocas oportunidades (II. 32,45 , p.e.). Los Sancho sin barba son los de Gutiérrez Aragón, Hiller y Gavaldón, entre los que aquí estudiamos. Ya habíamos anotado antes el "problema" con el Sancho/Cantinflas, que por supuesto solo tiene el popular bigotito. Datos para la erudición, igual que aquel de que Rocinante no tiene color en El Quijote literario, como muchos otros de este tipo que bien podría cualquier ocioso esculcar ante el descuido cervantino en las puntualidades de la descripción -lo que no quiere decir que no sepa describir-; en Yates la ínsula ya no es Barataria sino "La esperanza", debido, tal vez a que en inglés no puede establecerse el juego entre ese nombre y "barato", que hace el narrador en Don Quijote literario. Claro, Rocinante sigue con este nombre en todas las versiones, aunque tampoco pueda hacerse el juego

27 Tal como lo afirma Barthes (1991: 56), “la obra no está rodeada, designada, protegida, dirigida por ninguna situación, ninguna vida práctica está allí para decirnos el sentido que hay que darle; siempre tiene algo de 'citacional': la ambigüedad en ella es pura: por prolija que sea, posee algo de la concisión pítica, palabras conformes a un primer código (...) y sin embargo abierta a muchos sentidos, porque estaban pronunciadas fuera de toda situación -salvo la situación misma de la ambigüedad: la obra está siempre en situación profética". 
de palabras literario entre "rocín" y "antes", lo que nos devuelve a los problemas de la traducción en otro idioma, materia de la expresión que también está implicada en las versiones cinematográficas en inglés, en este caso las de Hiller, Yates y Wells; el retablo de maese Pedro, ya no es retablo, ya no es "titerera morisma" en Yates, sino actores de "carne y hueso" -dentro de la ficción-; las novelas ejemplares: Grisóstomo y Marcela, Cardenio y Lucinda, El capitán cautivo, Leandra y Vicente, El curioso impertinente, sobre cuya inclusión hay crítica aun dentro del mismo Don Quijote, desaparecen en las versiones cinematográficas, aunque en la de Gutiérrez Aragón se introduce la de Cardenio y Lucinda, que logra empatar con la historia de don Quijote 28 ; los extensos discursos directos de los personajes, algunos muy célebres: sobre las armas y las letras, sobre la Edad de Oro, sobre el oficio de la prostitución, son cercenados, apenas aludidos u omitidos las más de las veces en todas las versiones; $y$, por último, y a excepción otra vez de la versión española para TV29, los eventos escatológicos y el lenguaje soez que no pocas veces circula entre Sancho y don Quijote son "limpiados" de estas versiones, ya sea eliminándolos o re-formulándolos: Bálsamo de fierabrás, el episodio de los batanes, etcétera.

Si se toman con más cautela, todos estos datos dispersos, y los muchos más que los lectores y cinéfilos encuentren, pueden dirigirse hacia interpretaciones que involucren ideas sobre problemas estéticos, político-ideológicos, morales, etc. ${ }^{30}$, que

28 Estas historias son generalmente contadas por nuevos personajes que se convierten así en narradores intradiegéticos o englobados por el narrador principal extradiegético (Genette: 1983), y que, por otra parte, son muy analépticas o retrospectivas. Esta analepsis en literatura no puede darse sino a través de una materia de la expresión, la palabra escrita; en cine, el flashback o retrospección suele ir de la palabra a la imagen.

29 Aquí Rocinante muestra una mayúscula erección en el episodio en que desea "refocilarse con las señoras facas"; don Quijote (Fernando Rey) se para de cabeza desnudo en su penitencia en Sierra Morena; Sancho defeca al lado de la pareja don Quijote/Rocinante, en el episodio de los Batanes; y se desagua por entrambas canales con el bálsamo de Fierabrás.

30 Reconociendo que tal vez estas palabras estén en realidad siempre imbricadas, a juzgar por una noción de cultura particular a la manera en que el hombre construye modos de vivir específicamente humanos (Cfr. Cárdenas, 2004: 52-53). creemos pertinente abordar en "la escuela". Después de hacer este ejercicio, llegamos a la conclusión, por una parte, de que Don Quijote literario, más que narración de eventos, es representación de discursos, particularmente de discurso directo y discurso reportado ${ }^{31}$. Todo él es muy escénico en el sentido del diálogo, obligando al ejercicio de la reconstrucción de las caracterizaciones a través del análisis de las intervenciones, a menudo muy extensas, de varias "páginas", de los personajes. Esta extensión, más que la de la narración de los mismos eventos, es un primer problema para quienes hacen las versiones para cine o para TV, quienes se ven obligados a recortarlas o a suprimirlas. Toda esta "ilusión de que quienes hablan son los personajes" o la misma voz del narrador, introduce continuos juegos de palabras, que plantean graves problemas a los traductores a otros idiomas: casi podríamos concluir, so pena del esperpento, que cada lengua plantea su propia estética; que no hay versión transpuesta fiel al Don Quijote, y que, por tanto, deben leerse desde sus propios discursos, sin olvidar, claro, que la interpretación es útil y más si se parte de los mismos textos. Por otra parte, es muy difícil mantenerse al margen de los problemas ideológico-políticos ${ }^{32}$ que el Don Quijote y las versiones generan. Mañas Martínez (2006), por ejemplo, hace un juicioso estudio de la versión cinematográfica de Rafael Gil (1947), en plena dictadura del general Franco, en España, para mostrar "la abierta manipulación ideológica" 33 a que conduce el tratamiento, a partir de la selección, cortes, omisiones totales, música, incorporaciones de

31 Los discursos reportados son el indirecto y el indirecto libre (entre otros). Véase toda la tipología en Rimmon Kenan (1983: 109-116) para su definición. En El Quijote encontramos extensos discursos en estas formas, que para el cine obligan la reconstrucción. Como ejemplo, léase el discurso que el narrador hace de lo que dijo el dueño de la venta, en el momento en que don Quijote es armado caballero: "(...) y así, le dijo que andaba muy acertado en lo que deseaba y pedía (...) y que él, asimismo, en los años de su mocedad, se había dado a aquel honroso ejercicio (...) Díjole también que en aquel su castillo..." (I. 3).

32 A este respecto, cabe traer a colación a Bajtin (1992), para quien todo signo es ideológico, al punto de que no hay ideología sin lenguaje.

33 Diríamos mejor "encubierta" en la medida en que necesitó el estudio. Otro apunte para la academia. 
datos en la película ${ }^{34}$. Esto lo hace, claro está, después de presentar "la ideología" del franquismo, extraída de discursos, textos escritos, etc., para concluir que Gil "no se limita simplemente a difundir a Cervantes, sino que lo difunde según exigía la ideología oficial de la época”. Algunos de nuestros apuntes, ahora se entiende, tienen esta abierta predisposición hacia estas miradas.

\section{Bibliografía}

Albaladejo, Tomás. (1992). Semántica de la narración: la ficción realista. Madrid: Taurus.

Aumont, J. y otros. (1985). Estética del cine. Barcelona: Paidós Comunicación.

Bajtin, Mijail. (1989). Teoría y estética de la novela. Madrid: Taurus.

Bajtin, Mijail. (1992). El marxismo y la filosofía del lenguaje. Madrid: Alianza Editorial.

Barthes, Roland. (1980). Mitologías. México: Siglo XXI Editores.

Barthes, Roland. (1991). Crítica y verdad. México: Siglo XXI Editores.

Bloom, Harold. (1997). El canon Occidental. Barcelona: Anagrama.

Borges, J. L. (1980). Sobre los clásicos. En: Nueva antología personal. Barcelona: Bruguera.

Cárdenas P., A. (2004). Elementos para una pedagogía de la literatura. Bogotá: Universidad Pedagógica Nacional.

Carmona, Ramón. (1996). Cómo se comenta un texto fílmico. Madrid: Cátedra.

Eco, Umberto. (1977). Tratado de semiótica general. España: Lumen.

Eco, Umberto. (1981). Lector in fábula. Barcelona : Lumen.

Genette, Gérard. (1983). Nouveau discours du récit. Paris. Editions du Seuil.

Genette, Gérard. (1989). Palimpsestos. La literatura en segundo grado. Madrid: Taurus.

34 Mencionamos algunos trazos que la autora del artículo trabaja: la dignificación de don Quijote omitiendo la ridiculización del mismo; omitir todo discurso escabroso o escatológico; omitir los episodios que ella llama subversivos (Ginés de Pasamonte y los galeotes); omitir los discursos sobre la literatura -muchos en el Don Quijote literario-y mencionar los referidos a las armas o a la guerra; omitir todo lenguaje, condición -de los personajes- o evento que atente contra la doctrina cristiana y presentar los que le son de provecho, etcétera.
Cortamos aquí este artículo, de manera abrupta, con la idea de aportar, si no de modo explícito, provocaciones a la lectura ${ }^{35}$ de Don Quijote y al estudio más profundo y sistemático de estas y otras versiones cinematográficas y televisivas, con la certeza de que la capacidad de la literatura para crear mundo abre las posibilidades de lectura, las cuales son múltiples en la medida en que se abordan los efectos estéticos, poéticos, cosmovisionarios, culturales, junto a los propios del lenguaje.

Lukács, George. (1975). Teoría de la novela. El alma y las formas. Mexico: Grijalbo.

Mañas M., María del Mar. (2006). Don Quijote de La Mancha de Rafael Gil. Anales cervantinos. Volumen XXXVIII. pp. 67-93

Metz, Christian. (1971) Langage et cinéma. Paris: Larousse.

Metz, Christian. (1979) Psicoanálisis y cine. Barcelona: Gustavo Gili.

Nieto, José. Don Quijote de la Mancha. Música y cine. En http://cvc. Cervantes.es/actcult/quijote_musica/ Nieto/htm.

Ong, J.Walter. (1987). Oralidad y escritura. Tecnologías de la palabra. México: Fondo de cultura Económica.

Porter, M. y González, P. (1988). Las claves del cine. Barcelona: Arín.

Ramonet, Ignacio. Propagandas silenciosas. Venezuela. Valquiria (sin año de publicación).

Rimmon Kenan, Shlomith. (1994) Narrative Fiction: Contemporary Poetics. London: Clays.

35 Como se afirma en Cárdenas (2004: 129), “(...) detrás de la literatura permanecen en estado de latencia sensibilidades, historias, culturas y visiones de mundo, las cuales atraen de manera necesaria emociones, afectos, mitos, creencias, actitudes, valores, ideologías y concepciones de arte, poesía, lenguaje, ficción, estética, belleza, que conforman la experiencia y el saber propios de la comunidad. Este condensado estético lo concretan factores similares, típicos del fuero del lector. Ninguno de sus elementos es absoluto en cuanto la literatura arrastra la huella del hombre y, como tal, es una forma de su quehacer histórico y cultural; adicionalmente, su vocación humanista ambiciona luchar contra el olvido del hombre y recuperar el sentido de trascendencia, ambas apetencias absolutamente históricas e ideológicas. Todo esto se vuelca en la experiencia lectora". De igual forma, cabe admitir que las instancias cinematográfica, televisiva y teatral son otras tantas interpretaciones de la literatura, frente a las cuales cabe destacar que lo que allí se produce son versiones o formas abductivas que amplifican las posibilidades del mundo creado (Ibíd, 211ss). 